\title{
ASSOCIATION OF LICHEN PLANUS AND HEPATITIS C VIRUS
}

\author{
Lekkala Sreedevi', Jinkala Sreekala², Inturi Chandra Sekhar Reddy
}

${ }^{1}$ Civil Assistant Surgeon, Department of Dermatology, Government Medical College, Anantapur.

${ }^{2}$ Civil Assistant Surgeon, Office of Director of Health.

3Professor and HOD, Department of Dermatology, Kurnool Medical College, Kurnool.

ABSTRACT
BACKGROUND
Several dermatological manifestations of HCV infection have been described during the past 10 years, which include
leukocytoclastic vasculitis, porphyria cutanea tarda, mixed cryoglobulinemia, lichen planus, etc. The association of HCV and LP
depends mainly upon the prevalence of HCV infection.

AIM

The aim of the present study is to know the incidence of lichen planus and its association with HCV.

\section{SETTINGS AND DESIGN}

A prospective study done from August 2000 to January 2002 at Department of DVL, Kurnool Medical College, Andhra Pradesh.

\section{METHODS AND MATERIAL}

Routine urine and blood examination, Liver and Renal function tests, Anti-HCV test, HBsAg detection were done in all patients with lichen planus. Anti HCV antibodies was detected using ELISA-II. PCR and liver biopsy were done among patients positive to antiHCV antibodies.

\section{STATISTICAL ANALYSIS}

Statistical analysis is done by the chi-square test with Yate's correction. Corresponding P values are considered significant at value $<0.05$.

\section{RESULTS}

Anti-HCV antibodies are found in $8(19.04 \%)$ patients with LP and in one control (2.3\%) by ELISA-II. Out of 8 patients with HCV antibodies, 6 were positive for HCV-RNA, which was detected by RT-PCR in serum samples. Erosive LP is observed in five out of 8 patients $(62.5 \%)$ with HCV infection as against six out of 34 patients (17.64\%) without HCV infection. A statistically significant association $(\mathrm{P}=0.019)$ exists between erosive LP and HCV infection.

\section{CONCLUSION}

The present prospective study has shown that HCV is the main correlate of liver disease in patients with LP especially in oral erosive LP. Finally, our results strongly recommend that all patients with LP especially oral erosive lesions should be syste mically screened for the presence of HCV infection.

\section{KEYWORDS}

Hepatitis Virus, Lichen Planus, Polymerase Chain Reaction, Liver Biopsy.

HOW TO CITE THIS ARTICLE: Sreedevi L, Sreekala J, Reddy ICS. Association of lichen planus and hepatitis c virus. J. Evolution Med. Dent. Sci. 2016;5(55):3767-3769, DOI: 10.14260/jemds/2016/863

\section{INTRODUCTION}

Many viruses cause hepatitis as part of their spectrum of illness. But, only those viruses that cause hepatitis as their primary or predominant pathology were only named as hepatitis viruses. To date, seven hepatitis viruses (A-G) are recognised.[1]

HCV is a single stranded RNA virus responsible for most cases of post transfusional hepatitis. The most common presentation of HCV infection is chronic active hepatitis, which

Financial or Other, Competing Interest: None.

Submission 30-05-2016, Peer Review 28-06-2016,

Acceptance 04-07-2016, Published 11-07-2016.

Corresponding Author:

Dr. Lekkala Sreedevi,

Department of Dermatology,

Government Medical College and Government General Hospital,

Anantapuramu,

Andhra Pradesh, India.

E-mail: drsreelekkala@gmail.com

DOI: 10.14260/jemds/2016/863 manifests as wide spectrum of liver damage ranging from mild chronic hepatitis to cirrhosis and even hepatocellular carcinoma.[2]

Several dermatological manifestations of HCV infection have been described during the past 10 years, which include leukocytoclastic vasculitis, porphyria cutanea tarda, mixed cryoglobulinemia, lichen planus, polyarteritis nodosa, urticaria, erythema nodosum, and erythema multiforme.[3]

The first case of LP was described in patient with chronic hepatitis and HCV antibodies in 1991 by Makni.[4] Since then, numerous cases of LP associated with HCV infection have been published. The reported prevalence of HCV infection in patients with LP show wide variations from 3.8\% in France.[5] to $62 \%$ in Japan.[6]

The association of HCV and LP depends mainly upon the prevalence of HCV infection. The aim of the present study is to know the incidence of lichen planus and its association with HCV. 


\section{MATERIALS AND METHODS}

The present study was conducted on clinically diagnosed cases of lichen planus in the Outpatient Department of Dermatology, Kurnool Medical College and Hospital, Kurnool, for a period of 18 months (August 2000 to January 2002). Forty-two patients presenting with lichen planus were included in this study. They constitute cases not only from Kurnool town, but also from neighbouring villages. Ethical committee has approved to do this study and informed consent has taken from patients.

A detailed history including the age, sex, occupation, socioeconomic status, duration of the disease, present and past illness, family and personal history, blood transfusion history were recorded as per the proforma. The diagnosis is based mainly on clinical examination and confirmed by histopathological findings.

All the patients with lichen planus attending to the department were included in this study. Lichenoid eruptions were excluded. Routine urine and blood examination, Liver and Renal function tests, Anti-HCV test, HBsAg detection were done in all patients with lichen planus.

42 individuals with lichen planus and without any evidence of liver diseases were also included in this study under control group. Control group was investigated for liver function tests, Anti-HCV antibodies.

Anti-HCV antibodies were detected with commercial second generation Enzyme-Linked Immunosorbent Assay (ELISA-II). In positive ELISA-II cases, Reverse TranscriptasePolymerase Chain Reaction (RT-PCR) was performed to detect serum HCV-RNA. In patients with HCV-RNA, a liver scan and percutaneous liver biopsies were done.

Statistical analysis was done by the chi-square test with Yate's correction. Corresponding $\mathrm{P}$ values are considered significant at value $<0.05$.
Data collected from 42 cases clinically diagnosed as lichen planus for a period of 18 months (August 2000 - January 2002) formed the basis of this study.

Most of the cases were observed in the age group of 31-50 years was $42.84 \%$ followed by $21-30$ years $(19.04 \%)$. The incidence of LP being slightly higher in males (54.76\%) than females (45.24\%) and the male and female ratio is 1.2:1.

Out of 42 patients only cutaneous lesions were observed in 17 patients $(40.48 \%)$, both cutaneous and mucosal lesions in 13 members (30.96\%), mucosal involvement alone in 10 cases (23.80\%), and nail involvement only in 2 cases (4.76\%).

Abnormalities in one or more liver function tests were found frequently in lichen planus patients. Raised liver enzymes among lichen planus patients were depicted in Table No:1. None of the patients has prothrombin abnormalities. No significant difference was seen in relation to raised bilirubin levels in between the two groups.

\begin{tabular}{|c|c|c|c|}
\hline Characteristic & $\begin{array}{l}\text { Lichen } \\
\text { Planus } \\
\text { No. (\%) }\end{array}$ & $\begin{array}{l}\text { Controls } \\
\text { No. }(\%)\end{array}$ & $\begin{array}{c}\mathbf{P} \\
\text { Value }\end{array}$ \\
\hline Increased ALT & $14(33.3)$ & $4(9.5)$ & 0.022 \\
\hline Increased AST & $12(28.57)$ & $3(7.1)$ & 0.029 \\
\hline Increased Bilirubin & $3(7.14)$ & $3(7.1)$ & 1.00 \\
\hline $\begin{array}{l}\text { Reversed A/G ratio } \\
\text { (Hyperglobulinemia) }\end{array}$ & $10(23.8)$ & $2(4.7)$ & 0.036 \\
\hline $\begin{array}{l}\text { Increased Prothrombin } \\
\text { time }\end{array}$ & 0 & 0 & - \\
\hline HBsAg & $1(2.38)$ & $2(11.9)$ & 0.61 \\
\hline Anti HCV antibodies & $8(19.04)$ & $1(2.3)$ & 0.029 \\
\hline \multicolumn{4}{|c|}{$\begin{array}{c}\text { Table 1: Liver Screening Protocols of Patients with Lichen } \\
\text { Planus and Controls }\end{array}$} \\
\hline
\end{tabular}

Anti-HCV antibodies were found in $8(19.04 \%)$ patients with LP and in one control (2.3\%) by ELISA-II. Out of 8 patients with HCV antibodies, 6 were positive for HCV-RNA, which was detected by RT-PCR in serum samples (Table No.2).

\section{RESULTS}

\begin{tabular}{|c|c|c|c|c|c|c|}
\hline $\begin{array}{c}\text { Sl. } \\
\text { No. }\end{array}$ & $\begin{array}{c}\text { Age/ } \\
\text { Sex }\end{array}$ & Clinical Type & $\begin{array}{c}\text { Abnormal } \\
\text { LFT }\end{array}$ & $\begin{array}{c}\text { HCV- } \\
\text { RNA }\end{array}$ & $\begin{array}{c}\text { Liver } \\
\text { Scan }\end{array}$ & $\begin{array}{c}\text { Liver } \\
\text { Biopsy }\end{array}$ \\
\hline 1 & $38 / \mathrm{M}$ & Cutaneous LP & + & + & Cirrhosis & Cirrhosis \\
\hline 2 & $50 / \mathrm{M}$ & Buccal erosive & + & + & Normal & Normal \\
\hline 3 & $48 / \mathrm{F}$ & Buccal erosive & + & - & - & Normal \\
\hline 4 & $50 / \mathrm{M}$ & Cutaneous LP & + & + & CPH & - \\
\hline 5 & $50 / \mathrm{M}$ & Erosive and reticulate mucosal LP & + & + & - & - \\
\hline 6 & $25 / \mathrm{M}$ & Cutaneous and mucosal reticulate LP & + & - & Portal \\
\hline 7 & $68 / \mathrm{F}$ & Buccal erosive & + & + & Hypertension & Normal \\
\hline 8 & $38 / \mathrm{F}$ & $\begin{array}{c}\text { Cutaneous, buccal and genital erosive } \\
\text { LP }\end{array}$ & + & + & Normal \\
\hline \multicolumn{7}{|c|}{ Table 2: Clinical and Laboratory Results in Eight Patients with LP and HCV Antibodies } \\
\hline
\end{tabular}

CPH-Chronic persistent hepatitis; CAPH-Chronic active persistent hepatitis.

Mucosal LP (75\%) was the most commonly associated clinical entity with HCV infection (Table No.3). Erosive LP was observed in five out of 8 patients (62.5\%) with HCV infection as against six out of 34 patients (17.64\%) without HCV infection. A statistically significant association $(\mathrm{P}=0.019)$ exists between erosive LP and HCV infection.

\begin{tabular}{|c|c|c|}
\hline $\begin{array}{l}\text { Clinical } \\
\text { Variety }\end{array}$ & $\begin{array}{l}\text { No. of Cases with } \\
\text { HCV Antibodies }\end{array}$ & Percentage \\
\hline $\begin{array}{c}\text { Cutaneous lesions } \\
\text { only }\end{array}$ & 2 & $25 \%$ \\
\hline $\begin{array}{c}\text { Cutaneous + } \\
\text { Mucosal lesions } \\
\end{array}$ & 2 & $25 \%$ \\
\hline Mucosal only & 4 & $50 \%$ \\
\hline Total & 8 & $100 \%$ \\
\hline \multicolumn{3}{|c|}{$\begin{array}{l}\text { Table 3: Showing Percentage of Hepatitis C Virus } \\
\text { Infection in Relation to Site of Involvement }\end{array}$} \\
\hline
\end{tabular}

\section{DISCUSSION}

HCV, ever since it was discovered in 1989, has gained importance not only because it is the principal cause of post 
transfusion chronic hepatitis, but also because of its association with innumerable number of extrahepatic disorders.

As indicated in Table No.2, lichen planus associated with HCV infection occurs chiefly in the fifth to seventh decades (50\%) and men (62.5\%) were frequently affected. All patients with LP and HCV infection had abnormal liver function tests. Clinically, the lesions of HCV-related LP are similar to those of classical LP.

In this study, a statistically significant association $(\mathrm{P}=0.019)$ exists between erosive LP and HCV infection. Conversely, Cribier $\mathrm{B}$ et al[5] Ingafou $\mathrm{M}$ et al[7] Nicolas Dupin MD et al [8] found no significant association between LP and HCV infection. These discrepancies maybe due to overall prevalence of HCV infection in the general population or other unknown epidemiological factors.

In the present study, serum HCV-RNA is detected by RTPCR in $75 \%$ of the LP patients with anti-HCV antibodies indicating an infective status, which is comparable $79 \%$ and 94\% reported by Santander et al[9] and Carrozzo M et al [10] respectively.

On liver scan, $33.33 \%$ of the patients with LP and HCV-RNA showed indirect signs of cirrhosis and portal hypertension in this study, which is slightly less than that of $54 \%$ reported by Sanchez Perez et al[11] This is due to fact that LP without liver dysfunction either histological and on scan may have HCVRNA positivity occasionally as reported by Nagao $\mathrm{Y}$ et al.[6] Similar findings are observed in 3 patients in the present study.

The histological evidence of chronic active hepatitis, persistent hepatitis, and cirrhosis is seen in $50 \%$ of patients with HCV-RNA in the present study. This is in accordance with the study of Lodi $G$ et al[12] where the observed histological evidence was $60 \%$. In contrast, a lower incidence was reported by Rebora A[13] $11.3 \%$ and Sanchez Perez et al[11] 23\%.

In this study, raised transaminase levels and reversed A/G ratio is frequently observed in LP patients than in controls with significant $P$ value of $<0.05$. All patients with HCV-RNA had raised transaminase levels. These results are in line with Carrozzo et al[10] study. In contrast, Sanchez Perez et al[11] showed no significant difference in liver function test between LP patients and controls.

Carrozzo M et al[10] and Sanchez Perez et al[11] documented that females constitute $74 \%$ and $70 \%$ of patients with HCV infection and LP respectively. In contrast in this study, $62.5 \%$ of the patients were men. This difference is mainly dependent on incidence of sex ratio of LP in general population and may also due to the fact that females do not seek medical advice in India.

As per this study, the prevalence of HCV antibodies in LP is $19.04 \%$, which is significantly higher than in control group (2.5\%) with P value 0.016. Sanchez Perez et al[11], Bell man et al[14], Michele M et al[15], Santander et al[9] reported 20\%, 23\%, $28.8 \%, 38 \%$. Nagao Y et al $[6]$ reported $62 \%$.

The present prospective study has shown that HCV is the main correlate of liver disease in patients with LP especially in oral erosive LP. Further studies are required to elucidate the mechanism of association. Finally, our results strongly recommend that all patients with LP especially oral erosive lesions should be systemically screened for the presence of HCV infection. Early detection of HCV helps to reduce the incidence of HCV related disorders in the population and also gives more favourable response to treatment. Awareness of LP with HCV for effective management. HCV detection by HCV RNA PCR test is more useful and confirmatory.

\section{ACKNOWLEDGEMENTS}

We are thankful to staff of Department of Microbiology and Pathology for their help while doing this research work.

\section{REFERENCES}

1. Abraham P, John TJ. Hepatitis C: a review with particular reference to the Indian scenario. Indian J of Medical Microbiology 1995;13(1):5-14.

2. Hoofnagle JH. Hepatitis C: Clinical spectrum of disease. Hepatology 1997;26(3 Suppl 1):15S-20S

3. Schwaber MJ, Zlotogorski A. Dermatological manifestations of hepatitis C infection. Int J Dermatol 1997;36(4):251-4.

4. Mokni M, Rybojad M, Puppin D, et al. Lichen planus and hepatitis C Virus. J Am Acad Dematol 1991;24 (5 Pt 1):792.

5. Cribier B, Garnier C, Laustriat D, et al. LP and HCV infection: an epidemiological study. J Am Acad Dermatol 1994;31:1070-2.

6. Nagao Y, Sata M, Tanikawa K, et al. LP and HCV in the northern Kushu region of Japan. Eur J Clin Inv 1995;25(12):910-4.

7. Inagafou M, Porter SR, Scully C, et al. No evidence of HCV infection of liver disease in British patients with oral LP. Int J Oral Maxillofac Surg 1998;27(1):65-6.

8. Dupin N, Chosidow O, Lunel FF, et al. Oral LP and HCV infection: a fortuitous association? Arch Dermatol 1997;133(8):1052-3.

9. Santander C, De Castro M, Monzon GC, et al. Prevalence of HCV infection and liver damage in patients with LP. Hepatology 1994;20:238A

10. Carrozzo M, Gandolfo S, Carbone M, et al. HCV infection in Italian patients with oral LP: a prospective casecontrol study. J Oral Pathol Med 1996;25(10):527-33.

11. Perez SJ, De Castro M, Buezo GF, et al. LP and HCV: prevalence and clinical presentation of patients with LP and HCV infection. Br J Dermatol 1996;134(4):715-9.

12. Lodi G, Carrozzo M, Harris K, et al. HCV associated oral lichen planus: no influence from hepatitis $\mathrm{G}$ virus coinfection. J Oral Pathol Med 2000;29:39-42.

13. Rebora A, Rongioletti F. Lichen planus and chronic active hepatitis. Acta Derm Venereol (Stockh) 1994;64:52-6.

14. Bellman B, Reddy RK, Falanga V. Lichen planus associated with hepatitis C. Lancet 1995;346:1234.

15. Mignogna MD, Lo Muzio L, Favia G, et al. Oral lichen planus and HCV infection: a clinical evaluation of 263 cases. Int J Dermatol 1998;37(8):575-8. 